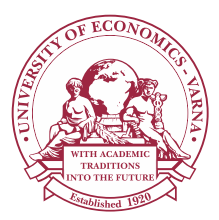

Izvestiya Journal of Varna University of Economics 2 (2021)

IZVEST I YA

Journal of Varna University of Economics

http://journal.ue-varna.bg

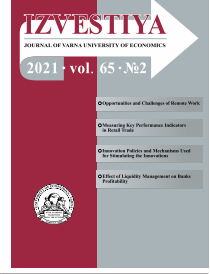

\title{
MEASURING KEY PERFORMANCE INDICATORS IN RETAIL TRADE
}

\section{Michal STOYANOV ${ }^{1}$}

${ }^{1}$ Department of Economics and Management of Commerce, University of Economics, Varna, Bulgaria. E-mail: michal.stojanov@ue-varna.bg

JEL: L81, L10

Key words:

retail trade, gross margin, operating margin,

inventory turnover.

\begin{abstract}
IThe tendency of business entities to cope with the challenges of the environment in which they operate is determined by the state and development of a complex system of evaluation indicators describing the condition and performance of the company and their time dynamics. They serve to objectively measure the extent to which the individual economic operator meets the conditions by which to be assigned to the group of successful business agents. In traditional retail trade, the most significant indicators for business evaluation are: gross (profit) margin, operating margin, turnover of inventories, gross return on investment in inventories, gross profit per employee, etc. The paper examines the key economic performance indicators of the three leading retail chains in the retail sales of fast moving consumer goods (FMCG) in Bulgaria.

(C) 2021 University of Economics - Varna
\end{abstract}

Citation: STOYANOV, Michal (2021). Measuring Key Performance Indicators in Retail Trade. Izvestiya Journal of Varna University of Economics, 65 (2), pp. 161 - 175.

DOI: 10.36997/IJUEV2021.65.2.161

\section{Introduction}

At the beginning of the third decade of the 21 st century, the economic ability of market participants to survive in an intensely competitive environment is determined by the assessments and their time change in certain key indicators of their business activity. The economic strength of each economic agent determines its suitability to meet the challenges of the local, regional, national and global market environment in which it is positioned for active business operations. In the retail trade, several key indicators are of leading importance that can be assessed and thoroughly studied. They 
are gross (profit) margin, operating margin, turnover of inventories, gross return on investment in inventories, gross (profit) margin per employee and others.

The main aim of this work is based on a theoretical summary of the essence of selected key performance indicators for retail trade to perform their quantification for the three leading retail chains in retail trade in Bulgaria and to make an appropriate analysis of the quantitative estimates obtained and economic interpretation of their dynamics.

The research objects of the present study are the three leading retail chains for the sale of fast moving consumer goods (FMCG) in the country. The data on the market shares of the selected commercial operators are estimated by the analyst company ICAP, as for the five-year period from 2014 to 2018 they change from $11.7 \%$ for Kaufland Bulgaria, 5.3\% for Lidl Bulgaria and 5.1\% for Billa Bulgaria to $14.1 \%$ for Kaufland Bulgaria, $8.5 \%$ for Lidl Bulgaria and $7.0 \%$ for Billa Bulgaria (Kaufland Bulgaria EOOD \& KO KD, 2015; Kaufland Bulgaria EOOD \& KO KD, 2019). The market positions of the selected companies are retained as they occupy the first three places at the top of the ranking of companies in retail trade, but they mark a sustainable development in the direction of increasing sales and hence market shares, which is a result achieved against the overall increase in retail sales of FMCG in the country by over BGN 11 billion (Georgieva, 2019) and total retail sales volume by over BGN 43 billion in 2018 (National Statistical Institute, 2019). In its economic logic, this is a clear signal of the continuing concentration in the sector and the increasing power and economic importance of the economic agents of exchange selected for research.

A specific point of the present study is the use of certain commercial terminology, which has acquired popularity and is part of the specific language of commercial entrepreneurship, but in its legal nature and normative application in accounting standards, is in some relative controversy. To this end, comments will be made in the statement to express both the commercial and accounting nature of the indicators.

Another accompanying limitation of the work is related to established corrections in the reporting data of selected indicators for previous periods, which are disclosed in subsequent reporting periods of the surveyed companies. For this purpose, in the technical and economic calculations the reporting data with the best up-to-date are used as a priority, which takes into account the recalculations made for each of the previous years of the research period 2014-2018 extracted from the unconsolidated financial statements of the selected trade operators. As a last limitation of the research carried out, we determine that when conducting a comparative study for longer periods of time, it is advisable to eliminate the impact of price changes in the value of performance indicators of commercial activity. However, since in the present study the emphasis is on the comparison between individual economic indicators within the country, the 
Michal Stoyanov.

Measuring Key Performance Indicators in Retail Trade

impact of price changes would be the same for all surveyed participants and would affect their values equally, therefore this transformation at comparable prices has not been taken out. However, it should be taken into account when carrying out the economic interpretation of the results.

\section{Theoretical overview of key performance metrics in retail trade}

For each active business entity there is a universal set of performance indicators, with the help of which a diagnosis of economic condition in the business can be given, which predetermines its opportunities for successful market performance and potential threats to its existence. In its entirety, it can be assessed both statically and dynamically, the latter having greater cognitive significance and is applied in the complex assessment of the economic condition of each trader.

Further, the study can be expanded by a comparative study of the same indicators between similar economic entities, which will serve to determine the benchmark for the best performance in a business activity or segment of the market. But, "even without specific comparative data available, a skilled analyst will scan the revenue and expense categories on an income statement as a matter of course over a number of time periods to see if any of them seem out of line or are trending adversely within the particular company's experience" (Helfert, 2001, p. 105). In retail trade, where the specific entrepreneurship of resale is realized, in which the products, own produced goods and materials purchased by the representative agents of the product exchange are sold to end users, it is appropriate to focus on economic evaluation and analysis of the system of the following important business performance metrics:

1. Gross (profit) margin or the average level (percentage) of the sales markup, which is traditionally calculated on the basis of the selling price, in which the net sales revenue of the commercial companies is usually expressed. If the basis of this ratio is changed and it is the reference of the cost of goods sold, then we will get the average level of the gross margin to the acquisition price of products at which the business agent works. Or, despite the difference in the absolute values of these two expressions, the relative (percentage) estimates obtained describe the trader's gross level of profitability. The gross margin metric itself is obtained as the ratio of gross income or gross profit and the reported in income statement value of cost of goods sold (COGS). The main point for the implementation of the technical and economic calculation is the clarification of the information sources, for obtaining the assessment of the indicator, which requires interpretation of the essence of the accepted in commercial theory and in this paper for unambiguous categories of the gross profit and the gross margin defined in International Accounting Standards (IAS 1) and National Accounting Standards (NAS 1). 
Despite the accounting identity of the two indicators, it should be "noted the existing difference between the economic categories of gross margin and gross profit" (Terezova, 2009, p. 117), where we accept the understanding that in its economic content the category of gross margin is more appropriate for the cumulative expression of the effects that remain in favor of the trader from his business activity. By this mean "is a key number for assessing the performance of an enterprise and for predicting future profitability" (Revsine et al., 2014, p. 66). Gross margin is "sometimes referred to as gross profit, a term that can be misleading, since expenses must be subtracted to determine profit and by this gross margin is the amount available to cover expenses and provide profit" (Easterling et al., 2012, p. 45).

Gross margin in commerce is the value expression of the difference between net sales revenue and the income statement amount of the cost of the goods sold (cost of sales) and thus reflects the price of the trade service, formed as the sum of trade margins, discounts, markdowns and mark-ups. Thus, gross margin arises as a result of "the difference between the net sales and the net purchase value of goods sold" (Vladimirova \& Nikolova, 2017, p. 196). It should be noted that "the main elements of gross margin are operating expenses and profit from trade operations" (Danchev \& Grozdeva, 2010, p. 577). Therefore, the magnitude of the economic effect of gross margin ensures the coverage of all company expenses and, together with other nonmerchant-specific revenues (other operating income), leads to the formation of the profit that is used for tax purposes (corporate income tax). From this position, the formal expression for obtaining the gross margin is:

Gross margin percentage to the sales price $=\frac{\text { Gross margin }}{\text { Net sales revenue }} \times 100=$

$=\frac{\text { Net sales revenue }- \text { Cost Of Goods Sold }}{\text { Net sales revenue }} \times 100$

Gross margin (percentage) to the purchase price (Markup) $=\frac{\text { Gross margin }}{\text { Cost Of Goods Sold }} \times 100=$ $=\frac{\text { Net sales revenue }- \text { Cost Of Goods Sold }}{\text { Cost Of Goods Sold }} \times 100$

And in the general case Gross margin to the sales prices $<$ Gross margin to the purchase price.

2. Operating margin or average level (rate) of operating profit. A key point in this 
Michal Stoyanov.

Measuring Key Performance Indicators in Retail Trade

metric is the use of the operating profit of the commercial company, which expresses the difference between the value of the absolute amounts of operating income and operating expenses (costs).

$$
\text { Operating margin }=\frac{\text { Operating profit }}{\text { Net sales revenue }} \times 100
$$

The main objective of this ratio evaluating is to measure the operational efficiency of the management of trade operations.

3. The specificity of the commercial activity, where the group of "Inventories" is dominated by the subgroup "Goods", allows to calculate the more specific indicator of turnover of inventories or for short of goods or only stocks. However, in general, the turnover of the average inventories is assessed in all business activities. Essential in the technology of technical calculations and economic interpretation of the results is the moment when on an annual basis the income statement gives the annual value of sales made by the company, and they represent most of the commercial company revenues for the period as accumulated from beginning to the end of period volume, until the value of inventories is given not through their annual accumulation represented in the balance sheet, but through their final snapshot volume in the current assets of the balance sheet. This "reflects the fact that the income statement number represents activity over the entire accounting period, whereas the balance sheet number only represents assets or equity as of the end of the accounting period" (Guenther, 2005, p. 76). Therefore, it is appropriate to present them as an average value, which is assessed in the most general case as the average value of the sum of the initial for the current period (final for the previous period) and final value at the end of the current period. This allows obtaining a conditionally adjusted or modified value, which is applied only for the purposes of obtaining the specific indicator of average inventory turnover.

Inventory turnover (turns) $=\frac{\text { Net sales revenue }}{\text { Average inventories }}$

An important point in obtaining the assessment is the consideration with the applied accounting approach for the way in which the baseline indicators used in the metrics are reported. This is because net sales revenue is recorded at selling prices, while inventories are valued at the cost of their acquisition. Hence, the possibility of alternatively obtaining the indicator by using the cost of goods sold instead of revenues from the net sales of goods. 
$(3.2)$

Inventory turnover (turns) $=\frac{\text { Cost Of Goods Sold }}{\text { Average inventories }}$

In the Bulgarian literature (Kostova, 2010, p. 159) (Todorov, 2008, p. 112) (Nenov, 2012, p. 321) (Danchev \& Grozdeva, 2010, p. 460) and in the practice of business evaluation the first indicator has greater popularity. Based on the indicator Inventory turnover (turns) 3.1 and / or 3.2 within the length of the reporting period measured in days, a derivative indicator for the average duration in days of one turnover can be obtained:

Inventory turnover (turns) $=\frac{\text { Days of the period }}{\text { Average inventories }}$

Each business entity "must make trade-offs in deciding the optimum level of inventory and thus the desirable rate of inventory turnover" so as to achieve profitable investment in inventory, lowering costs for financing and carrying inventory and ensuring the continuity of sales (Wahlen \& Baginski \& Bradshaw, 2010, p. 287).

4. Gross margin return on inventory investment - GMROII, indicates how many units of gross income are obtained due to 1 or 100 units of investment in inventories.

Gross margin return on inventory investment $=\frac{\text { Gross margin }}{\text { Average inventories }} \times 100$

5. Gross margin per employee (GM/E) is used to measure the contribution that one full-time employed person in the company has to the acquisition of the gross margin effect.

Gross margin per employee $=\frac{\text { Gross margin }}{\text { Number of full-time employees }}$

An alternative measure of labor productivity in a commercial company is the composite economic indicator of the level of labor productivity, which is expressed through average sales made on one person from the staff (NS/E).

Net sale revenue per employee $=\frac{\text { Net sale revenue }}{\text { Number of full-time employees }}$ 
Michal Stoyanov.

Measuring Key Performance Indicators in Retail Trade

An important point in obtaining both indicators is the derivation of the summary estimate of the average number of employees, as an average value for a certain reporting period. In the present work, the estimates of the annual average number of employees are derived from the annual reports of the surveyed trade organizations.

6. Level of operating expenses (OER), which will quantify the volume of operating costs required for the realization of a 1 or 100 units of sales.

(6)

Operating expense ratio $=\frac{\text { Operating expenses (incl. Cost Of Goods Sold) }}{\text { Net sales revenue }} \times 100$

A specific moment for obtaining this indicator is the possibility to include the reported (book) value (cost) of goods sold in the value of the sum of operating expenses. With the help of this indicator the system of metrics for evaluation of the operational efficiency of the business is developed, through which the concept of the factor determinism of the profit rate in the commercial company is supplemented. The aim is to keep the indicator below 1 (100), which will determine the ability of the business with current revenues to cover the operating costs of the commercial activity.

In conclusion of the theoretical part, we can point out that there are specifics in the definitions and practice of obtaining the measures of certain economic indicators in specific business activities and in particular in commerce. They comply with the economic uniqueness and the established trade tradition, but in their fundamental economic essence they are measures that in a very universal way, are trying to give a complex picture of the overall business performance of any agent of product exchange by analogy valid for each business unit. In practice, this means that "a little thought and common sense should suggest which measures are likely to produce the most helpful insights into company's efficiency" (Brealey \& Myers \& Allen, 2010, p. 714).

\section{Measuring key performance indicators in retail trade in Bulgaria}

In 2018, the market leader in retail trade in the segment of fast-moving consumer goods Kaufland Bulgaria is positioned in first place in terms of revenues from sales of goods in the amount of BGN 1,547,393 thousand. The leading position of the company is confirmed in terms of operating margin, which has its highest value of $7.2 \%$ in 2016 and despite the registered decrease to the lowest estimate of 5.6\% in 2018, this measure of the efficiency of the largest commercial operator in the country, confirms its better performance compared to the other participants included in this study for each of the years of the period (see Table 1). 
Table 1

Key performance indicators of the three leading retail chains for fast moving consumer goods in retail trade in Bulgaria by years for the period 2014-2018

\begin{tabular}{|c|c|c|c|c|c|c|c|c|c|c|c|}
\hline \multirow{3}{*}{ 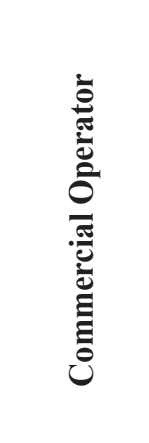 } & \multirow{3}{*}{ Periods } & \multirow{3}{*}{ 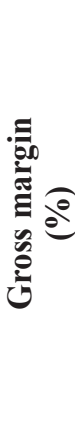 } & \multirow{3}{*}{ 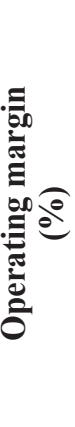 } & \multicolumn{4}{|c|}{ Inventory turnover } & \multirow{3}{*}{ 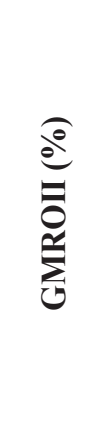 } & \multirow{3}{*}{ 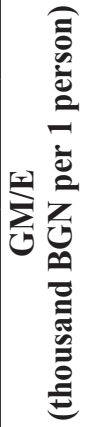 } & \multirow{3}{*}{ 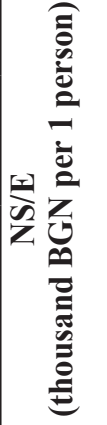 } & \multirow{3}{*}{ 중 } \\
\hline & & & & \multicolumn{2}{|c|}{$\begin{array}{l}\text { to net sales } \\
\text { revenue }\end{array}$} & \multicolumn{2}{|c|}{$\begin{array}{l}\text { to cost of } \\
\text { goods sold }\end{array}$} & & & & \\
\hline & & & & 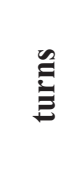 & స్త & $\cong$ & స్త & & & & \\
\hline \multirow{5}{*}{$\begin{array}{l}\text { Kaufland } \\
\text { Bulgaria }\end{array}$} & 2014 & 14,2 & 6,4 & 9,5 & 38,2 & 8,2 & 44,6 & 135,8 & 26,6 & 187,0 & 96,2 \\
\hline & 2015 & 13,6 & 7,2 & 9,8 & 37,4 & 8,4 & 43,2 & 133,1 & 25,9 & 190,0 & 105,5 \\
\hline & 2016 & 10,4 & 7,2 & 10,5 & 34,7 & 9,4 & 38,7 & 108,8 & 21,4 & 206,8 & 109,3 \\
\hline & 2017 & 24,8 & 6,1 & 11,6 & 31,4 & 8,7 & 41,7 & 287,9 & 61,7 & 249,4 & 95,4 \\
\hline & 2018 & 24,5 & 5,6 & 12,2 & 29,8 & 9,2 & 39,5 & 300,0 & 66,6 & 271,8 & 96,0 \\
\hline \multirow{5}{*}{$\begin{array}{c}\text { Billa } \\
\text { Bulgaria }\end{array}$} & 2014 & 24,4 & $-1,9$ & 13,3 & 27,4 & 10,1 & 36,2 & 325,2 & 34,7 & 142,1 & 103,3 \\
\hline & 2015 & 24,2 & 0,9 & 14,5 & 25,2 & 11,0 & 33,3 & 351,3 & 35,0 & 144,5 & 99,8 \\
\hline & 2016 & 25,1 & 0,9 & 15,0 & 24,4 & 11,2 & 32,5 & 375,7 & 38,1 & 152,1 & 99,1 \\
\hline & 2017 & 24,4 & 0,7 & 14,7 & 24,8 & 11,1 & 32,9 & 359,0 & 37,7 & 154,1 & 100,1 \\
\hline & 2018 & 23,8 & 0,3 & 14,6 & 25,1 & 11,1 & 32,9 & 346,8 & 38,2 & 160,4 & 101,2 \\
\hline \multirow{5}{*}{$\begin{array}{c}\text { Lidl } \\
\text { Bulgaria }\end{array}$} & 2014 & 19,5 & $-4,7$ & 11,7 & 31,2 & 9,4 & 38,7 & 228,3 & 61,8 & 317,0 & 105,6 \\
\hline & 2015 & 21,6 & 1,5 & 11,9 & 30,6 & 9,3 & 39,1 & 258,1 & 75,3 & 348,1 & 99,4 \\
\hline & 2016 & 23,3 & 3,7 & 13,1 & 27,8 & 10,1 & 36,3 & 305,6 & 83,2 & 357,0 & 97,4 \\
\hline & 2017 & 24,3 & 3,2 & 14,4 & 25,4 & 10,9 & 33,6 & 348,7 & 86,5 & 356,1 & 97,7 \\
\hline & 2018 & 25,3 & 4,2 & 15,1 & 24,2 & 11,3 & 32,4 & 380,9 & 90,5 & 358,3 & 97,3 \\
\hline
\end{tabular}

Source: Author's calculations based on data from Kaufland Bulgaria, Billa Bulgaria, Lidl Bulgaria.

Despite the leadership in this metric for Kaufland Bulgaria in comparative terms, the company does not achieve this economic efficiency, as a consequence of the higher level of gross margin, the exchange agent who works with the highest level of gross 
Michal Stoyanov.

Measuring Key Performance Indicators in Retail Trade

margin is Lidl Bulgaria, which in 2018 registered an estimate of $25.3 \%$, compared to $24.5 \%$ for Kaufland Bulgaria and $23.8 \%$ for Billa Bulgaria. This in itself is a business situation in which taking the leading position on a key performance indicator is not enough to obtain a similar situation in all measures of the trader's performance metrics. In practice, this is an argument behind the understanding that excellence in a given economic aspect is achieved through relative compromising in other areas. In business, this means that it is difficult to achieve maximum performance in relation to all economic indicators, because this requires significant resources and advanced management skills, and commercial operators should apply a business approach to balance and mutual compensation between the indicators, against the background of the overall positive development and the existing resource constraint.

At the beginning of the researched period in 2014, Lidl Bulgaria had a negative assessment of the operating profit margin of $-4.7 \%$, which is a natural result of the expansion strategy of the company in the country, which started its business four years earlier at the end of 2010. This is also the last moment with a negative expression of the operating profit, as in the other periods a steady increase of the indicator to its highest value of $4.2 \%$ is demonstrated in 2018 . There is a similar development profile in Billa Bulgaria with a negative assessment of the indicator of the level of operating profit margin at the beginning of the period of $-1.9 \%$ in 2014, which was followed by an incremental increase to $0.9 \%$ in 2015 , which the company failed to further develop in the direction of an upward trend, so the company ends the period with a relatively insignificant estimate of $0.3 \%$ in 2018. All this, however, is achieved against the background of the most stable development of gross margin, as Billa Bulgaria is the only company that does not report significant amplitudes in the level of gross margins between the lowest values of $23.8 \%$ in 2018 to the highest of $25.1 \%$ in 2016 . The decrease in the level of gross margin is a reaction to competitive pressure between leaders in the consumer goods retail trade sector.

The structure of the revenues of the surveyed trade companies confirms that in the retail trade sector the largest share have the revenues from sales of goods and services, for example in 2018 for Kaufland Bulgaria this share is 98.5\%, for Lidl Bulgaria is $99 \%$ and for Billa Bulgaria is $99.2 \%$. This is an unequivocal confirmation of the basic economic nature of the activity of trade companies in the economic system. Of course, there are other sources in the revenues of each commercial operator, but they have negligible shares and can be the result of transactions with currencies and financial instruments, participation in capital markets and as transfers between related companies or "accidental" (extraordinary) processes with positive results for the company. From this position the indicators for the inventory turnover, measured in number of turns and in days of one turnover, are estimated. The undisputed leader here is Lidl Bulgaria 
with estimates of 15.1 turnovers in 2018, which is the fastest turnover measured in days for one turnover with an estimate of 24.2 days, but it should be noted that this value is achieved only at the end of the period or is a result of inventory management policies and product portfolio in the company. Such finding is completely logical in the context of the format definition of this retailer as a hard discounter and the related with this product structure, pricing policy and intensive promotional activity. If we summarize the performance in terms of turnover for the whole period, then Billa Bulgaria performs relatively best, but after 2016 this company began to register a certain slowdown in the average speed in the realization of inventory. Conditionally the weakest in terms of turnover of the three companies is the performance of Kaufland Bulgaria with the lowest reading of 9.5 turns in 2014, which transformed as significant average duration of one turnover of 38.2 days. Such a situation is caused by the extremely diverse product portfolio in the retail chain and the presence of a relatively considerable volume of goods with relatively lower turnover, both in the food and non-food segment of the offered commodity range. The findings would be similar for the surveyed reporting periods, if we apply to the assessment of the turnover indicators the cost of the goods sold instead of the net sales revenues. Such a technical change in the calculations causes two distinctions, one is related to the conditionally less favorable value of the estimates, expressed as lower values for turnover and a longer average duration in days of one turnover, another point is that the most unfavorable values the metrics for Lidl Bulgaria are achieved one year later in 2015.

The ranking of the three commercial operators with regard to return on investment in inventories metrics shows that the most successful in terms of product portfolio management ability is Lidl Bulgaria, which at the end of 2018 reached an estimate of $380,9 \%$. Although this finding for the best performance can be interpreted from another position, as in four $(2014,2015,2016$ and 2017) of the five surveyed years the leadership in the indicator fell to Billa Bulgaria. This is a good signal for the ability of the representative of the REWE concern to form a product offer in accordance with the preferences of the served customers. The most unsatisfactory of the three companies is the performance of Kaufland Bulgaria, which always over the years occupies the last position and registered the lowest value of the three compared economic entities of only $108.8 \%$ in 2016 , which compared to the highest score of $300 \%$ in 2018 clearly demonstrates that the company is aware of the critical situation in this area and has taken important steps to change the management of the product range.

Labor productivity measured as gross margin per employee distinguishes Lidl Bulgaria as the undisputed leader among the compared companies for each reporting year of the surveyed period. The highest score of the indicator was achieved in 2018 of BGN 90.5 thousand on average per staff member. However, the indicator has undergone 
Michal Stoyanov.

Measuring Key Performance Indicators in Retail Trade

the most significant development at Kaufland Bulgaria, as the lowest estimate of BGN 21.4 thousand per employed person in 2014 reached BGN 66.6 thousand per one person in 2018 or an absolute increase of BGN 45.2 thousand per one person or a growth rate of $310.9 \%$. As with most indicators, Billa Bulgaria clearly demonstrates the sustainability in the development of gross margin per employee measured by a standard deviation with an estimate of $\sigma_{\text {GMROE Billa }}=$ BGN 1,557 thousand per staff member, with values of $\sigma_{\mathrm{GMROE} \text { Kaufland }}=\mathrm{BGN} 19,504$ thousand per person from the employed in Kufland Bulgaria and $\sigma_{\text {GMROE Lidl }}=$ BGN 10,144 thousand on employee from the work force working for Lidl Bulgaria.

This confirms that the marketing strategy of Billa Bulgaria is aimed at maintaining stability in the development of the economic process. This means that in the competitive conditions of retail trade in fast moving consumer goods, each company applies an individual market strategy, which measured by certain key performance indicators manages to ensure the desired economic effects and achieve business objectives set. In addition, the alternative form for measuring labor productivity obtained as the average net sales per employee (NS/E) was evaluated. The highest estimate of the indicator was achieved in 2018 of BGN 358.3 thousand sales per employed person at Lidl Bulgaria. As again the most significant development, the indicator has undergone at Kaufland Bulgaria, as from the lowest estimate of BGN 187 thousand sales per employed person in 2014 it reaches BGN 271.8 thousand sales per employed person in 2018 or a relative increase of $145.3 \%$. According to this indicator as well, Billa Bulgaria demonstrates a stable positive development, which is estimated as an average annual growth rate of $103.1 \%$.

Finally in the research, the level of operating costs was estimated, where the lowest estimate of $95.4 \%$ was achieved by Kaufland Bulgaria in 2017, which is a reaction to the highest value of $109.3 \%$ achieved by the same company a year earlier. Therefore, we can look for a rational explanation in the behavior of business entities, which, taking into account an unfavorable situation in a given indicator during a given reporting period, concentrate their decisions in the direction of its correction, which gives results in the next period. Overall, Lidl Bulgaria performs relatively well, as in four (2015, 2016, 2017 and 2018) of the five years, it managed to maintain its level below $100 \%$. At the end of the period, only Billa Bulgaria registered an estimate of $101.2 \%$, which partly explains the declining rate of the company's operating margin in 2018.

The given estimates for the key performance indicators of the retail trade activity of the leading operators in the trade sector in the country can give only one of the possible sections when performing a complex analysis of their company activity. This requires a more comprehensive approach to performing business diagnostics, in which the evaluation of key performance indicators has a leading place and importance. The 
analysis carried out confirmed the established understanding that "the company's own financial statements is the best source of information to know more about a company, its past performance, current health, and prospects for the future" (Revsine et al., 2014, p. 3) and confirms that "economic analysis is one of the main methods for studying economic reality" (Yonchev \& Terezova, 1998, p. 23), but they also "provide clues about what's really important - that is, what's likely to happen in the future" (Brigham \& Houston, 2018, p. 118).

\section{Conclusion}

The performed technical calculations, the received quantitative estimates and the economic interpretations made related to them, allow us to formulate the following more important conclusions:

First, in a comparative plan between the individual companies, the achievement of leading assessments on some indicators is associated with a less favorable position in others, which requires their consideration as a balanced system when looking for sustainability and comprehensive efficiency in economic development.

Second, the differences in the assessments of the key indicators of the individual trade operators are determined by their format specifics as retailers. At the same time, the state and dynamics of the market environment and competition and many other factors beyond the control of the company, as well as within its management, have a significant impact on the overall performance of the company.

Third, in the short run, the management decisions of individual operators sought as a reaction or achieving time stability in the development of economic indicators, or counteracting the deterioration in the dynamics of an indicator of activity, which gives results in subsequent periods. All this leads to an effect expressed in the relatively positive direction of development of all three operators towards the end of the surveyed time horizon.

Fourth, with the help of the presented system of key performance indicators it is confirmed that the dynamics in some metrics can be rationally economically justified with the changes in other of the given indicators, which is an expression of their interdependence and compensation.

Therefore, each trade company must conduct a systematic comprehensive and quantitative study of its business performance, which provides economic arguments for the effectiveness of management decisions and to create arguments about the need to make well-defined changes to successfully adapt to market challenges and successfully resist the competition pressure. Commercial operators must constantly improve their ability to study these and other key performance indicators, which is a prerequisite 
Michal Stoyanov.

Measuring Key Performance Indicators in Retail Trade

to get the most out of the resource allocation and which must be done in a dynamic, territorial and product aspect.

The conducted research can be further developed under the fulfillment of a specific condition, which is related to the possibility to significantly increase the cognitive value of the assessments, if they are assessed analytically or independently by stock keep units from the portfolios of commercial companies. However, this is achievable in the presence of operational information in high detail, derived directly from the information databases of commercial companies. If this is feasible, then combining information with its greatest time disaggregation will achieve a high level of complexity of economic analysis and information security of any managerial decision in trade and mainly in terms of product portfolio management and sales. Of course, the above indicators cannot present a comprehensive picture of the overall economic development of commercial agents, but they are an appropriate starting point for conducting a complex economic analysis of trade activity.

\section{References}

1. Billa Balgariya EOOD. (2015). Godishen finansov otchet 2014. [Online] Available at: https://portal.registryagency.bg/ (Accessed: 12.12. 2019).

2. Billa Balgariya EOOD. (2016). Godishen finansov otchet 2015. [Online] Available at: https://portal.registryagency.bg/ (Accessed: 12.12. 2019).

3. Billa Balgariya EOOD. (2017). Godishen finansov otchet 2016. [Online] Available at: https://portal.registryagency.bg/ (Accessed: 12.12.2019).

4. Billa Balgariya EOOD. (2018). Godishen finansov otchet 2017. [Online] Available at: https://portal.registryagency.bg/ (Accessed: 12.12.2019).

5. Billa Balgariya EOOD. (2019). Godishen finansov otchet 2018. [Online] Available at: https://portal.registryagency.bg/ (Accessed: 12.12.2019).

6. Brealey, R. \& Myers, S. \& Allen, F. (2010). Principles of Corporate Finance. 10th Edition, McGraw-Hill/Irwin.

7. Brigham, E. \& Houston, J. (2018). Fundamentals of financial management. 15th Edition, Cengage Learning, Inc.

8. Danchev, D., \& Grozdeva, D. (2010). Vavedenie v targovskiya biznes. Veliko Tarnovo, Faber.

9. Easterling, C. \& Flottman, E. \& Jernigan, M. \& Wuest, B. (2012). Merchandising Mathematics for Retailing. 5th Edition, Pearson.

10. Georgieva, M. (2019). Pazarat na barzooborotni stoki dostigna 11 mlrd. lv. prez 2018 g. [Online] Available at: https://www.capital.bg/biznes/ kompanii/2019/01/27/3380677_pazarut_na_burzooborotni_stoki_dostigna_11_mlrd_ 
lv/ (Accessed: 04.01.2020).

11. Guenther, D. (2005). Financial reporting and analysis. New York, McGRAW-HILL.

12. Helfert, E. (2001). Financial Analysis Tools and Techniques. 1st Edition, McGraw-Hill Education.

13. Kaufland Balgariya EOOD \& KO KD. (2015). Godishen finansov otchet 2014. [Online] Available at: https://portal.registryagency.bg/ (Accessed: 12.12. 2019).

14. Kaufland Balgariya EOOD \& KO KD. (2016). Godishen finansov otchet 2015. [Online] Available at: https://portal.registryagency.bg/ (Accessed: 12.12. 2019).

15. Kaufland Balgariya EOOD \& KO KD. (2017). Godishen finansov otchet 2016. [Online] Available at: https://portal.registryagency.bg/ (Accessed: 12.12. 2019).

16. Kaufland Balgariya EOOD \& KO KD. (2018). Godishen finansov otchet 2017. [Online] Available at: https://portal.registryagency.bg/ (Accessed: 12.12. 2019).

17. Kaufland Balgariya EOOD \& KO KD. (2019). Godishen finansov otchet 2018. [Online] Available at: https://portal.registryagency.bg/ (Accessed: 12.12. 2019).

18. Kostova, N. (2010). Finansovo-schetovoden analiz. Varna, Aktiv-K.

19. Lidl Bulgaria. (2015). Godishen finansov otchet 2014. [Online] Available at: https://portal.registryagency.bg/ (Accessed: 12.12. 2019).

20. Lidl Bulgaria. (2016). Godishen finansov otchet 2015. [Online] Available at: https://portal.registryagency.bg/ (Accessed: 12.12. 2019).

21. Lidl Bulgaria. (2017). Godishen finansov otchet 2016. [Online] Available at: https://portal.registryagency.bg/ (Accessed: 12.12. 2019).

22. Lidl Bulgaria. (2018). Godishen finansov otchet 2017. [Online] Available at: https://portal.registryagency.bg/ (Accessed: 12.12. 2019).

23. Lidl Bulgaria. (2019). Godishen finansov otchet 2018. [Online] Available at: https://portal.registryagency.bg/ (Accessed: 12.12. 2019).

24. Natsionalen Statisticheski Institut. (2019). Prodazhbi na drebno - 2018 godina. [Online] Available at: https://www.nsi.bg/bg/content/1623/prodazhbi-nadrebno (Accessed: 04.01.2020).

25. Nenov, T. (2012). Biznes dignostika. Varna, Nauka i ikonomika.

26. Revsine, L. \& Collins, D. \& Johnson, B. \& Mittelstaedt, F. \& Soffer, L. (2014). Financial Reporting \& Analysis. McGraw-Hill.

27. Terezova, S. (2009). Upravlenieto na razhodite po obrashtenie - iztochnik na konkurentno predimstvo na targovskite firmi. Ikonomicheski alternativi (Ikonomicheski i sotsialni alternativi), VI(6), 115-127.

28. Todorov, G. (2008). Finansovo-schetovoden analiz na predpriyatieto. Varna, IK Geya-Print.

29. Vladimirova, Y. \& Nikolova, I. (2017). Ikonomika na targoviyata. Sofiya, 
Michal Stoyanov.

Measuring Key Performance Indicators in Retail Trade

Izdatelski kompleks - UNSS.

30. Yonchev, T. \& Terezova, S. (1998). Planirane i analiz na stopanskata deynost na targovskite firmi. Sofia, UI Stopanstvo.

31. Wahlen, J. \& Baginski, S. \& Bradshaw, M. (2010). Financial reporting, Financial statement analysis, and Valuation: A Strategic Perspective. 7th Edition, South-Western Cengage Learning, Inc. 